\title{
Forms of City Gas Supply System and Development of Natural Gas Market in China
}

\author{
Zhanying Ren, Renshu Yang \\ School of Mechanics and Civil Engineering, China University of Mining and Technology, Beijing, China
}

\begin{abstract}
The research paper is going to discuss about the development of the city gas supply system and the natural gas market in China and find out how does the development of city gas supply system and natural gas market can influence the environment of China. Nowadays, China is concerning the environmental protection and reduces the problems of pollution. So, by improving the city gas supply system and choosing a better source of city gas in China is necessary (natural gas). The research paper will briefly introduce the different types of city gas using in China, the advantage of choosing natural gas, some major policies (projects) have been made by the government, and some challenges which are facing by China in natural gas market.
\end{abstract}

Keywords- Forms; City Gas Supply System; Development; Natural Gas Market.

\section{INTRODUCTION}

The economic reform of China has been implemented for more than 30 years. In these 30 years, the growth rate of China's economy has increased rapidly. Unprecedentedly, China has undergone a biggest economic growth in the world during the past decades. According to the information of National Bureau of Statistics of China in 2009, it said the per capita GDP in China has reached 22,698 Yuan, comparing with 2002 which was only 9398 Yuan; it has risen for more than a double [1]. Besides that, there is almost 60 times greater than that in 1978 since the per capita GDP in china was only 381 Yuan in 1978. Since the economy has developed rapidly, it has raised the living standard of people in China and enhanced the pace of urbanization. Once the urbanization rate increased, people will enjoy higher income as well. Coal energy has dominated the supply of China for many years. But nearly half of coal is burnt directly with minimal or no emission controls by hundreds of thousands of small boilers [2]. As coal is still the main fuel for heating in China, air pollution and water pollution tend to be more serious in cities. So, the importance of developing the city gas system is needed.

\section{City GAS SUPPLY IN CHINA}

In China, the supply of city gas can be divided by three parts. (i) Manufactured gas (coal gas), (ii) liquid petroleum gas, (iii) natural gas.

\section{A Manufactured gas (coal gas)}

In 2009, the volume supply of coal gas in China was $3,615,507$ (10,000 cu.m). When compared with volume supply of coal gas in 1999 which was 1,320,925 (10,000 cu.m), it is almost tripled. Manufactured gas (Coal gas) is important for lighting, heating, and cooking purposes throughout most of the nineteenth century and the first half of the twentieth century. The manufacturing process typically consisted of the gasification of flammable materials, mostly from coal, also some wood and oil.

\section{$B$ Liquid petroleum gas (LPG)}

In 2009, the volume supply of LPG in China was 13,400,303 (tons).Compare with the supplied in 1999 which was only 7,612,684 (tons). It has more than tripled. Liquid petroleum gas (LPG) is a flammable mixture of hydrocarbon gases used as a fuel in heating appliances, vehicles, and cooking. The technological development of LPG transportation and storage provided China alternative source of city gas supply. In China, the supply of LPG can be divided as three parts, SINOPEC accounted for 32\%, CNOOC accounted for $31 \%$, and the imported from other countries such as Australia and Middle East accounted for 32\% [3].

\section{Natural gas}

The importance of natural gas has increased in the past decade because natural gas is one of the clean energy sources in the world. The China government knew that the air pollution which is caused by Coal burning. Some polluted component was released into the atmosphere across the country; air pollution in Northern China (e.g. Beijing, Lanzhou, Shanxi) is very serious. So, to reduce the pollution, new energy source must be provided. As the government started to concern the environmental problems in China, the government's priority task in the energy supply structure must be changed. According to the "BP Statistical Review of World Energy" in June 2010, China only reserves of natural gas for around 2.46 trillion $\mathrm{m}^{3}$, which only contained $1.3 \%$ of the total reserves of the world [4], as is shown in Figure 1.

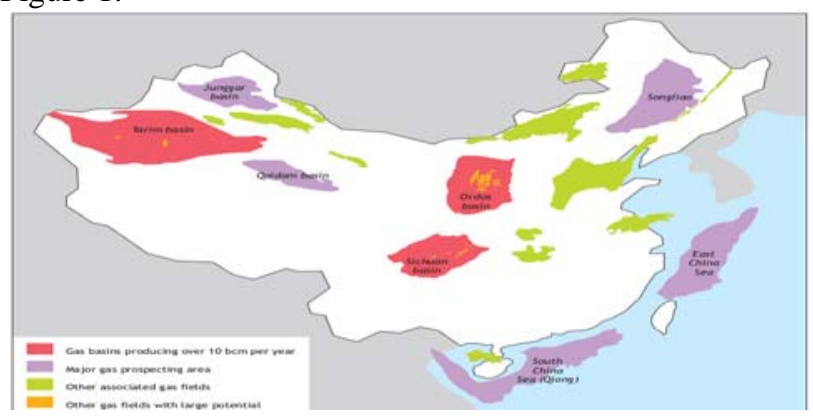

Figure 1. Gas resources in China. 
TABLE 1. Emission of Air Pollutants between Using Coal, Fuel Oil, and Natural Gas\{Note to comp: Please set "Note" below Table 1 also change "Fuel oil" and "Natural gas" to "Fuel Oil" and "Natural Gas"\}.

\begin{tabular}{|c|r|r|r|}
\hline \multicolumn{4}{|c|}{ Note: Emission of air pollutants (kg) } \\
\hline & Coal & Fuel oil & Natural gas \\
\hline $\mathrm{CO}_{2}$ & 6.2580 & 3.3320 & 2.1840 \\
\hline $\mathrm{SO}_{2}$ & 0.0506 & 0.0420 & 0.0002 \\
\hline $\mathrm{NO}_{\mathrm{X}}$ & 0.0218 & 0.0069 & 0.0026 \\
\hline
\end{tabular}

Sources: China Energy Statistical Yearbook (CESY) 2008, CNPC.

\section{THE ADVANTAGES OF CHOOSING NATURAL GAS IN CHINA}

\section{A Less air pollutants}

The importance of using natural gas in China has been concerned since the government encouraged fuel switching from coal and oil (LPG) to natural gas in order to reduce air pollution. Table 1 shows the emission of air pollutants between using Coal, Fuel oil, and natural gas.

For using natural gas, compare with using Coal and Fuel oil, the air pollutants produced during the manufacturing process is much lower. NOx and SO2 emissions can cause acid rain, and these two pollutants are harmful to human's body, it causes or worsens respiratory diseases such as emphysema, bronchitis and it may also aggravate existing heart disease.

TABle II. Three NATiOnAL Oil Companies’ Situation IN THE NATURAL GAS MARKET IN CHINA.

\begin{tabular}{|l|r|r|r|}
\hline & CNPCPetroChina & \multicolumn{1}{c|}{ Sinopec } & \multicolumn{1}{c|}{ CNO0C } \\
\hline Government share & $90 \%$ & $77.42 \%$ & $70.6 \%$ \\
\hline Total assets (USD million) & 139848 & 96658 & 23657 \\
\hline Income (USD million) & 110154 & 158938 & 11892 \\
\hline Net profit (USD million USD) & 20477 & 7458 & 4079 \\
\hline Net profitincome ratio & $18.6 \%$ & $4.7 \%$ & $34.3 \%$ \\
\hline Oil production (1 000 b/d) & 2298 & 96658 & 23657 \\
\hline Gas production (mceld) & 4458 & 774 & 560 \\
\hline
\end{tabular}

Sources: Company annual reports.

\section{$B$ Concerning the environmental protection}

Coal has been dominated for the energy supply in China for many years, although it is still remaining a large proportion of the energy supply, but the government has known that the damage to the environment which caused by Coal is very serious, because heavy reliance on coal has caused many air pollution in China. According to the "Law of the People's Republic of China on the Prevention and Control of Atmospheric Pollution", it is said that "This Law is formulated for the purpose of preventing and controlling atmospheric pollution, protecting and improving people's environment and the ecological environment, safeguarding human health, and promoting the sustainable development of economy and society." And it mainly concerns the "Prevention and Control of Atmospheric Pollution by the Burning of Coal.” By putting some Environmental Regulation and enforcement, the government tried to prevent the pollution effectively.

\section{SOME GOVERNMENT POLICIES (PROJECTS) IN DEVELOPING THE NATURAL GAS MARKET IN CHINA}

China's natural gas sector is dominated by three national oil companies: CNPC, SINOPEC, and CNOOC. The government share has $70-90 \%$ in these three oil companies. These three national oil companies took place during the reform of China in 1980s. Although the city gas supply operators were no longer restricted for the state owned enterprise and private companies and overseas investors were allowed to operate city gas supply business in China after the reform, but until now, many major projects and policies like the import of gas, building more infrastructures for natural gas supply is still put forward by these three national oil companies. These three national oil companies are still acting as an important role in the natural gas market in China, See Table 2.

\section{A Import of natural gas}

With the sustained and rapid economic growth of China, the demand of the natural gas has increased and the domestic natural gas production cannot fully meet the market demand in China. Table 3 below shows two of the national oil companies has signed some long term agreement for the "Liquid Natural Gas" sale and purchase with the suppliers which are from Australia, Indonesia, and Malaysia, etc. [5].

\section{TABle III. LONG TERM AgreEMENT Signed by TwO OF THE NATIONAL OIL COMPANIES \{ NOTE TO COMP: PLEASE CHANGE "SUPPLY SOURCE, DESTINATION TERMINAL, FIRST CARGO” TO “SUPPLY SOURCE, DESTINATION TERMINAL, FIRST CARGO”\}.}

\begin{tabular}{|c|c|c|c|c|c|c|}
\hline Buyer & Supply source & $\begin{array}{l}\text { Volume } \\
\text { (mtpa) }\end{array}$ & $\begin{array}{l}\text { Term } \\
\text { (years) }\end{array}$ & \begin{tabular}{|l|} 
Signing \\
date
\end{tabular} & \begin{tabular}{|l}
$\begin{array}{l}\text { Destination terminal } \\
\text { (Capacity - mtpa) }\end{array}$ \\
\end{tabular} & $\begin{array}{l}\text { First } \\
\text { cargo }\end{array}$ \\
\hline \multirow[t]{6}{*}{$\mathrm{CNOOC}$} & $\begin{array}{l}\text { Australia } \\
\text { NWS }\end{array}$ & 3.3 & 25 & $\begin{array}{l}2003 \\
\text { Dec }\end{array}$ & $\begin{array}{l}\text { Guangdong } \\
\text { (3.7) }\end{array}$ & $\begin{array}{l}2006 \\
\text { Jun }\end{array}$ \\
\hline & \begin{tabular}{|l|}
$\begin{array}{l}\text { Indonesia } \\
\text { Tangguh }\end{array}$ \\
\end{tabular} & 2.6 & 25 & \begin{tabular}{|l|}
2006 \\
Sep
\end{tabular} & $\begin{array}{l}\text { Fujian } \\
(2.6)\end{array}$ & $\begin{array}{l}2009 \\
\text { May }\end{array}$ \\
\hline & $\begin{array}{l}\text { Malaysia } \\
\text { Tiga }\end{array}$ & 3.0 & 25 & $\begin{array}{l}2006 \\
\text { Jul }\end{array}$ & $\begin{array}{l}\text { Shanghai } \\
(3.0)\end{array}$ & 2009 \\
\hline & QatarGas II & 2.0 & 25 & 2008 Jun & Multi-destination? & 2009 \\
\hline & \begin{tabular}{|l} 
Total (Portfolio) \\
\end{tabular} & 1.0 & 15 & 2009 Jan & Multi-destination? & 2010 \\
\hline & $\begin{array}{l}\text { Australia } \\
\text { QC LNG } \\
\end{array}$ & 3.6 & 20 & $\begin{array}{l}2009 \\
\text { May }\end{array}$ & & 2014 \\
\hline \multirow[t]{3}{*}{ CNPC } & QatarGas IV & 3.0 & 25 & $2008 \mathrm{Apr}$ & \begin{tabular}{|l} 
Jiangsu? \\
$(3.0)$
\end{tabular} & 2011 \\
\hline & \begin{tabular}{|l|} 
Shell \\
(Gorgon+)
\end{tabular} & 2.0 & 20 & $\begin{array}{l}2008 \\
\text { Nov }\end{array}$ & $\begin{array}{l}\text { Dalian? } \\
(3.5)\end{array}$ & 2011 \\
\hline & $\begin{array}{l}\text { ExxonMobil } \\
\text { (Gorgon) }\end{array}$ & 2.0 & 20 & $\begin{array}{l}2009 \\
\text { March }\end{array}$ & & 2014 \\
\hline Total & & 22.5 & & & & \\
\hline
\end{tabular}

B Developing more infrastructure for natural gas supply in the country

Since the infrastructure for natural gas is still very weak in China, the government has implemented some policies 
and projects of the exploration and the supply security of natural gas in China. Several projects for gas storage and pipeline interconnections are developing. The first underground storage, with a capacity of $1.6 \mathrm{bcm}$, was built in 2001 and located in the Dagang oilfield in Tianjin, to ensure supply to Beijing and Tianjin.

\section{CHALLENGES OF DEVELOPING NATURAL GAS IN CHINA}

\section{A Main competitor is coal}

The domestic coal is very cheap and abundant in China. The price of gas is almost five times that of coal for the same unit of heat. Since there is still a large proportion of using coal gas in China, many industries are still using coal as the energy supply. The price disadvantage of gas compared to coal may dissuade many industries to use gas for their long term energy supply.

\section{B Huge investment of developing natural gas}

Gas is a huge investment and the investments include import, transport, store, distribute gas, upstream production and pipeline are very expensive. For example in Western Europe, they have invested for 750 billion Euros throughout the gas industry from 1960 to 2000. China would need more money to invest since the huge population and the big size of the country. So, financing such an investment is an important challenge of China's gas industry.

\section{Natural gas reserve is limited}

As mentioned in the above paragraphs, China only has 2.46 trillion $\mathrm{m}^{3}$, only $1.3 \%$ of the total reserves of the world. At the same time, the demand of natural gas keeps increasing rapidly. Shortage of natural gas reserve may occur if China doesn't have enough import of natural gas.

\section{CONCLUSIONS AND RECOMMENDATIONS}

After the economic reform of China, serious pollution was occurred during the manufacturing processes and transportation process. The appearance of natural gas could bring a cleaner energy to China in order to improve the environmental problem. Driven by the huge population, economic growth and increasing need for protecting the environment, natural gas will play as the important role in the future of energy supply in China.

Firstly, it is needed to explain and let more domestic industries to know that the advantages of using natural gas and the disadvantages of using coal. The main purpose of the government is to diversify its coal dominated energy supply in China in order to improve the serious air pollution. Secondly, it is also recommended to encourage more private and foreign investment in the natural gas market in China, because huge investment is needed to develop the natural gas market and until now, many major projects are still dominated by big three national oil companies. Increase the private and foreign investment can share the burden of the huge amount of money and foreign investors will bring some new technologies to contribute the development of natural gas in China. Lastly, develop more new supply ways of natural gas from other countries because the reserve is limited in China but the demand is increasing rapidly and some pricing policies of natural gas need major reform in order to compete with the cheap and abundant coal in China.

\section{ACKNOWLEDGMENTS}

The research work was supported by China University of Mining and Technology, Beijing.

\section{REFERENCES}

[1] P. Robert, Developing China's Natural Gas Market. Oxford University, pp. 68-69, 2002.

[2] K. Zhang, Strategic replacement situation and outlook of China oil-gas production area. Petroleum Exploration and Development Online, (5), pp. 35-38, 2012.

[3] BBC news, Disabilities in China's polluted Shanxi. March 2012, p. 52.

[4] National Bureau of Statistics of China, China N B O S O. The China Statistical Yearbook 2012. National Bureau of Statistics of China, Beijing, 2012.

[5] D. Xu, China Natural Gas Industry in Development. China development report, Beijing, 2011. 